Vol. 52, no. 2 (2014), pp. 331-350, doi: 10.14421/ajis.2014.522.331-350

\title{
THE APPREHENSIONS OF TRADITIONAL ULAMA TOWARDS WOMEN'S PARTICIPATION IN POLITICS IN NIGERIA
}

\author{
Adebayo Rafiu Ibrahim \\ University of Ilorin, Nigeria \\ email:adrafhope@yahoo.com
}

\section{Abstract}

Throughout the political history of Islam, women played significant political roles in the affairs of muslim states. This, however, has not been the situation in Nigeria where muslim women are skeptical about their involvement in politics, seeing it as an exclusively male domain. This has been so probably because of the voice of ulama against women's participation in politics or the general belief that politics is a dirty game which is not meant for women. The big question then is why do Nigerian ulama resist women's involvement in politics? Further, would muslims not stand the risk of losing theirpolitical potentiality should they remain indifferent to political participation by women? And, how do female muslim elites who have a flair for politics feel about their lack of political voice: would this not affect their spiritual or religious interests in the long run? This paper explores Islamic political history for the purpose of discovering the extent of muslim women's involvement in politics, and the reasons for the non-involvement of muslim women in the nation's politics from the viewpoint of the traditional ulama in the country.

[Sepanjang sejarah Islam, wanita memainkan peran penting dalam politik di banyak negara muslim. Namun, hal ini tidak terjadi di Nigeria, karena wanitanya ragu terhadap peran mereka di kancah politik yang memang didominasi oleh para lelaki. Ini terjadi karena ulama menentang keterlibatan wanita di politik serta pandangan bahwa politik itu kotor dan tidak sesuai untuk wanita. Pertanyaannya kenapa para ulama menentang wanita berpolitik? Lalu, apakah mereka tidak rugi secara politis jika tidak peduli dengan partisipasi wanita? Bagaimana juga para wanita muslim itu tidak 
merasa kurang bersuara dalam politik: apakah ini tidak mempengarubi spiritualitas dan kepentingan jangka panjang? Paper ini meneliti sejarah politik. Islam terkait dengan peran wanita di politik, juga alasan kenapa mereka tidak terlibat menurut kaum ulama tradisional di Nigeria.]

Keywords: Nigeria, woman and politics, traditional ulama

\section{A. Introduction}

The practical involvement of women in politics is receiving serious attention from those who strongly feel that they are being marginalized in the political realm and so cannot compete well with their male counterparts. The age-long dichotomy between male and female has been a matter of concern for scholars, hence the development of Gender Studies as an academic programme among political scientists, philosophers and theologians. ${ }^{1}$ In the contemporary period, the United Nations has come up with different measures to rescue women from the 'bondage' of men, such as the promulgation of Political Rights in 1947 and Equality in Work and Education in 1948, among others. ${ }^{2}$ This step led to the emergence of different Non-Governmental Organizations (NGOs) championing the cause of women's empowerment through sensitisation programmes, like seminars and conferences. For instance, the first United Nations Conference in the International Year of Women in Mexico in 1975. The second and third of its nature were held in Nairobi and Vienna respectively. Cairo also hosted the fourth World Conference on Women and Development in 1994, while a similar conference was held in 1995 in Beijing.

In Nigeria, the 1989 National Seminar on Women and Children which was held at Owerri ushered in serious agitation for the promotion of rights of women in Nigerian and this consequently led to the establishment of different NGOs, such as the National Council for Women's Societies (NCWS) and the National Council for Women

${ }^{1}$ Muhib O. Opeloye, "The Muslim Women and the Challenges of the Contemporary Time", Journal of Nigerian Association of Teachers of Arabic and Islamic Studies, vol. 9 (2006), p. 1.

${ }^{2}$ S.M. Jamiu, "An Appraisal of Sex, Politics and Polity Among the Nigerian Muslim Women", in The Muslim Woman and the Challenges of the Contemporary Society, ed. by Yahya Oyewole Imam (Plateau State Nigeria: NATAIS [Nigeria Association of Teachers of Arabic and Islamic Studies], 2008), p. 15. 
Politicians (NCWP), among others. ${ }^{3}$ In 1997, Nigeria hosted the African First Ladies Peace Mission Conference at Abuja. The numerous steps taken by Nigerian women led to the establishment of numerous women's commissions and agencies, such as Better Life for Rural Women, the Family Support Programme, the Family Economic Advancement Programme and the Ministry of Women Affairs and Social Development at both Federal and State levels. ${ }^{4}$

From all indications, it cannot be refuted that women had been subjugated by numerous traditional myths, cultures, and religions. Indeed, their subordinate position is almost universal across cultures and religions. Opeloye submitted that women were held in very low esteem among the ancient civilizations such as the Byzantines and Persians, and so was the case in the primordial religions like Hinduism and Buddhism. ${ }^{5}$ This is equally the view of Qutb who studied the position of women in Europe prior to the history of the movement for women's emancipation there; before and during the periods of serfdom and feudalism and till the industrial revolution took place in Europe. For Qutb, before the industrial revolution, women were looked upon as mere non-entities, and with the industrial revolution, their condition worsened, because family life was completely ruined, as women and children were forced to work in factories leaving the country-life for cities where morality was downplayed and no-one cared for their neighbours. ${ }^{6}$ On the plight of women following the revolution, Qutb submits:

But what did woman get as a result of this revolution? She was overlooked physically, had lost respect as well as her womanhood! She was denied even the natural pleasure of having a family, having children, living with them and of realizing her own true self by suffering for them and so have a true sense of well-being and magnanimity. She did, however, in place of these at last win the right to have equal wages with man, the only natural sright offered her by Europe. ${ }^{7}$

The transformation which had occurred for women at the advent of Islam is unequal in human history when compared to other cultures and civilizations which preceded it. The religion succeeded in not only

\footnotetext{
${ }^{3}$ Ibid., p. 17.

${ }^{4}$ Ibid.

${ }^{5}$ Opeloye, “The Muslim Women”, p. 1.

${ }^{6}$ Muhammad Qutb, Islam: The Misunderstood Religion (Riyadh: International Islamic Federation of Student Organizations, 2006), pp. 90-6.

${ }^{7}$ Ibid., pp. $90-5$.
} 
restoring to women their dignity and honour, by granting similar status to men, but also in protecting her rights as daughter, wife, mother and widow. However, it could not be denied that the rights accorded women in Islam had been trampled upon due to various socio-cultural influences which prominent muslim reformers of the $19^{\text {th }}$ century had seriously rebelled against. In Nigeria for instance, the 1804, Jihad leader, Shaykh Uthman Danfodiyo was not happy with the way and manner in which women were treated in the traditional Hausa society and even among the ulama of the period. He condemned what he called impious practices of the ulama who left their wives, daughters, treating them as slaves and neglecting them by not giving them adequate education. ${ }^{8}$

It seems there is historical evidence of muslim reformer in some countries such that muslim women have been active participants in politics and have attained positions of high political office. Turkey and Bangladesh have had heads of state in Tansu Ciller and Khalida Zia asrespectively. ${ }^{9}$ In Nigeria, the story is different as muslim women who engage in politics are looked down upon, while there some ulama who advocate against this practice believing it is not in the spirit of Islam.

\section{B. Traditional Ulama in the Nigerian Context}

Nasiru has classified the ulama into two groups in Nigerian context, namely traditional and modern scholars. According to him, the traditional scholars are well versed in the Quran, the Hadith, Arabic Grammar, Islamic jurisprudence and other branches of Arabic and Islamic studies. These are scholars who would not do what they think the Prophet did not do, and who prefer to follow his example, for example, by eating with their fingers instead of eating utensils; and sitting on the floor rather than on chairs. They hardly allow their women to go out at night, and when necessary, they go out fully veiled. They also leave their beards uncut and have formed the habit of always putting on their turban. They do not have any interest in western-style education which they see as kufr

${ }^{8}$ Abd Al-Karim Uthman, "The Socio-Economic Status of Women in Northern Nigeria: An Analysis of The 1804 Jihad Movement", Al-Ijtibad: Journal for the Islamization of Knowledge and Contemporary Issues, vol. 8, no. 1 (2010), p. 14.

9 Muqtedar Khan, "Constructing Identity in 'Glocal' Politics", American Journal of Islamic Social Sciences, vol. 15, no. 3 (1998), p. 97, http://works.bepress.com/cgi/ viewcontent.cgi?article $=1031 \&$ context $=$ muqtedar_khan, accessed 6 Jun 2014 . 
education or learning English which to them is kufr language. ${ }^{10}$ Describing further the characteristics of typical traditional scholars, Nasiru submits: ...they do not use any calendar even if it is prepared from the Arab world to calculate dates of the Islamic festivals. They have their own way of calculation. They do not dance or listen to non-Islamic music. They do not take pictures or use them to decorate their houses, because the Hadith says that angels would not enter houses on the walls of which are hung pictures of beings that live, eat or grow. They read out their sermons on Fridays in Arabic because that was how the Prophet used to address the people. ${ }^{11}$

A good example of the traditional ulama in south-western Nigeria is a group called the Bamidele Movement. Doi cited some of the practices of the group to have included growing of beard, shaving of the head, the arm pits and the private parts of the body. The movement believes that to leave these hairs unshaven for forty days would defile a person and his prayers. To the group, wearing of the turban is compulsory, while their women must be in purdah, and their daughters above the age of twelve must not go out of their parents' home without veiling themselves thereby making it difficult for men to see them and propose marriage. However, a young woman must inform her parents about the man she would like to marry. The man is then invited by the leader of the movement, and in a secluded place she then unveils herself for hisassessment. Such a man may or may not accept the proposal. Apart from this, the movement sees nothing good in western education and so holds tenaciously to Quranic education. ${ }^{12}$

Conversely however, the modern ulama are virtually the opposite of the traditional ones. In addition to having fairly sound knowledge of the Quran, Hadith and Islamic sciences, they have sound knowledge of westernstyle education, speak English fluently and see nothing wrong in listening to music and using cutlery and electronic gadgets. They do take and hang pictures and photographs. They have neutral attitude to shaving the beard, wearing the turban and making their wives wear the purdah. ${ }^{13}$ Although Nasiru identifies a third class of ulama that leans a

${ }^{10}$ Wahab O.A. Nasiru, “The Attitude of Traditional 'Ulama' to Muslim Female Education in Nigeria”, Muslim Education Quarterly, vol. 14, no. 2 (1997), p. 69.

${ }^{11}$ Ibid. 279-92.

${ }^{12}$ A.R. Doi, Islam in Nigeria (Zaria: Gaskiya Corporation Limited, 1984), pp.

${ }^{13}$ Nasiru, "The Attitude of Traditional Ulama", p. 69. 
little towards strict tradition and a little towards modern science, he does not give a vivid description of this class. The first two classifications will therefore be used in this study.

What is important to note is that both sets of scholars look at women's participation in politics with contempt. This may largely be as a result of the political atmosphere in Nigeria which is characterised by all sorts of vices, crises and acrimony which they feel is dangerous for muslim men let alone women. They are, however, divided on their attainment of positions of political leadership. Those who argue in favour of the participation of women in politics see nothing wrong in their attainment of political leadership. However, this paper is out to discuss why some muslim scholars are antagonistic of muslim women's participation in politics in Nigeria in spite of the evidence provided by its proponents.

\section{Women's Political Rights and Leadership}

It is unanimously agreed by jurists that a woman should not be appointed to the position of khalif which is the highest political and religious position in the muslim world. In the present disposition where the caliphate has gone into a state of oblivion, it implies that the principle can now be applied to a woman's appointment as the Head of State or Governor of a State. However, scholars are not unanimous on the interpretation of some Quranic verses that address women especially their leadership. It is believed by some that the Quran which reads "Men are in charge of women, because Allah has made the one of them to excel the other, and because they spend of their property..." is indicating that women are under the leadership of men who in turn are expected to protect, guide and help them. In his own submission, Sifawa believes that male leadership is the dispensation of nature from the dawn of creation and that they are expected to control women in both the physical and the moral domains. In turn, women are to concede to men in all sectors of their lives. ${ }^{14}$ To him, this does not in any way amount to discrimination against women, or that women are less than men, but is a natural phenomenon arising from division of labour and role differentiation. In his words, Islam regards men and women as created with differing but mutually complementary functions and so neither of the sexes should envy the other regarding what Allah has made the other to excel. ${ }^{15}$

${ }^{14}$ Muhammad Sifawa Abdullahi, "Women Leadership: An Islamic Perspective", Al-Nabda: A Journal of Islamic Heritage, vol. 2, no. 1 \& 2 (1999), p. 49.

${ }^{15}$ Ibid. 
As much as one agrees with this submission, it is only tenable in a family set-up; it cannot be extended to a situation where a woman by virtue of her education or profession rises from rank and file to a leadership position in a public setting. In such a situation, she does not need to deny herself such an opportunity by virtue of her gender and allow a junior officer to occupy such position. Discrimination against her by the authoritiesin this instance will amount to injustice. In our view, men and women are not destined to perform the same roles and responsibilities. A sort of natural division of labour is therefore instituted for the smooth running of the family. While a woman is naturally built to bear children, nurse and nurture them, the man is naturally built to protect and maintain the family. In the course of carrying out this responsibility, a woman does not in any way feel inferior to her male counterpart, and neither does the man feel superior to his female counterpart when performing his natural duty of protecting and maintaining the wife and children. That notwithstanding, in order to ensure the smooth running of the system, a leader needs to emerge, hence the Quranic reference to men as qawwāmūnà 'alà an-nisà' (protectors and maintainers of women) which qualifies them to assume leadership of the family. Therefore, the role of protecting and maintaining the family does not only qualify men to be the leader of home, but also because that is the design of Allah that one would be made to excel the other in any system. At the communal level, the Prophet enjoined the choice of a leader where at least three people reside. This verse therefore becomes another reference point that a man should be in position of leadership and not a woman. This is equally the interpretation of scholars like Sayyid Rashid Rida who argues that a family is a replica of society which must have a leader and who should be a man. ${ }^{16}$

One can however ask, what will be the situation in the instance where women are more educated, more energetic, more upright, morally intelligent and politically sagacious than some men? The answer to this question is aptly put by Qutb who advises that rare instances should not be generalised to make a case for normality. He writes:

The two sexes are thus found mixed up, as it were, in a medley. If you find a woman who is capable of ruling, dispensing justice, lifting heavy burdens and fighting in wars... and if you come across a man who can cook, do household chores or has got very tender motherly feelings for

${ }^{16}$ Muhammad Rashid Rida, Huqūq al-Nisà' fi al-Isläm: Nidä' al-Jins al-Latîf (Beirut: al-Maktab al-Islāmi, 1975), pp. 26-7. 
children or is very fickle emotionally and is visited by shifting moods, then you must remember that it is all natural, there is nothing unnatural about it. It is the logical result of the fact that each sex has in itself the germs of both sexes... The real problem stated briefly rather is: can all these extra-functions that a woman is called upon to perform substitute for her real and natural function? Does she in the presence of these no longer feel the desire for a home, children and a family? Above all, does she no longer feel the need for a male partner for the gratification of her sex instinct? ${ }^{17}$

While one does not stress the inferiority of women to men, it seems the contemporary agitation of women with men leaves many things to doubt considering the rate at which women are competing with men and at the same time trying to persuade men to allow them have a say in public affairs, as if there is any legal justification to substantiate men's domination in the society. The 1999 Nigerian Constitution Section 42 (1) clearly states that:

A citizen of Nigeria of a particular community, ethnic group, place of origin, sex, religion or political opinion shall not, by reason only that he is such a person be subjected to any form of discrimination.

To further emphasise the freedom of individuals to belong to any political party of choice and as well vie for any political office regardless of gender, Section 40 of the Constitution states:

Every person shall be entitled to assemble freely and associate with other persons, and in particular he may form or belong to any political party, trade union or any other association for the protection of his interests: Provided that the provisions of this section shall not derogate from the powers conferred by this Constitution on the Independent National Electoral Commission with respect to political parties to which that Commission does not accord recognition.

The recent development of introducing a separate Ministry for Women's Affairs further confirms our stand and the reference of the Prophet to women as the weaker gender that needs special attention and consideration. In our view, one need not request special treatment from someone she is competing or claiming equality with. Such a request implies admittance of the latter's superiority and the natural instincts in him that make him excel in society. Imitating him in his natural or physical manner also gives the impression that he possesses certain characteristics

${ }^{17}$ Qutb, Islam, p. 103. 
admired by her and this amounts to admitting these characteristics as against those that she also naturally possesses. This stand can be buttressed by the statement of Ibn Khaldun as cited by Sulaiman that:

The vanquished always want to imitate the victor in his distinctive characteristics, his dress, his occupation and all his other conditions and customs. The reason for this is that the soul always sees perfection in the person who is superior to it and to whom it is subservient. It considers him perfect either because it is impressed by the respect it has for him or because it erroneously assumes that its own sub-service to him is not due to the nature of defeat but to the perfection of the victor, if the erroneous assumption fixes in the souls it becomes a form of belief. The soul then adopts all manners of the victor and assimilates itself to him. This then is imitation. ${ }^{18}$

The argument is that such leadership positions like a Head of State or governor of a state should be reserved for men; as such offices are heavy burdens that could break the backs of women considering their biological and psychological nature and equally deserves to be discussed. One cannot rule out the fact that women undergo depression during which certain physiological and psychological changes are experienced by them. During this period, the nation or state's activity will be brought to a halt as they would not be able to function effectively in their administrative responsibility. There is no doubt that the monthly menstrual period of women, the pregnancy period, as well as the period immediately following childbirth can constitute a great impediment to effective leadership. Further, the excessive strains that accompany such periods may adversely affect the decisions of women in decision making positions. ${ }^{19}$ It is on this basis that Opeloye suggested that women who are fully matured and should have passed the age of menstruation or child bearing could be considered for appointment as judges, heads of legislative arms of government and other sensitive offices. ${ }^{20}$ He however does not also support that a woman be considered for the post of the chief executive of a government in view of a hadith of the Prophet which does not support it.

${ }^{18}$ I.K.R. Sulaiman, "The Shari'ah and the 1979 Constitution", in Islamic Law in Nigeria: Application and Teaching, ed. by S.K. Rashid (Lagos: Islamic Publication Bureau, 1986), p. 59.

${ }^{19}$ Opeloye, "The Muslim Women", p. 6.

${ }^{20}$ Ibid., p. 7. 


\section{Why the Apprehension?}

The traditional ulama apprehension towards muslim women's participation is basically premised on two major factors, namely the political climate of the country and the assumed position of muslim women in Islam which to them does not allow them to fully participate in politics. These shall now be considered.

\section{The Political Environment in Nigeria}

The political scene in Nigeria has not been rosy, as it is characterized by incessant riots, chaos and crises. The first offensive odour of political pandemonium was smelt right from the First republic which culminated in the truncation of the political independence given to Nigeria just two years later. The Action Group crisis of 1962 which consequently led to the declaration of a state of emergency was said to have recorded gross vandalisation of state-owned and privately owned property worth millions of naira as well as loss of lives. Operation wet $e^{21}$ of the 1965 elections in the Nigerian Western Regions left behind unforgettable casualties in the history of politics in Nigeria. The October 1963 election, therefore, was plagued by the disappearance of ballot boxes, papers, unfair counting and thuggery. This consequently led to the staging of the bloody first military coup led by Major Patrick Chukwuma Nzeogwu to check the hitherto unabated lawlessness that characterized the political scene of the country. Notable political moguls like the Prime Minister, Alhaji Tafawa Balewa, Chief Samuel Ladoke Akintola, Ahmadu Bello and many others were the sacrificial lambs that lost their lives in the process. ${ }^{22}$ The 1983 election was not free of electoral malpractices, as it was claimed that ballot boxes were thrown into the sea and lagoons in Ondo and Lagos States. ${ }^{23}$ Protests which followed the announcement of the elections culminated in the loss of over 300 lives and not less than a hundred houses as well as other inestimable property damage. ${ }^{24}$ Such has been the picture of politics in Nigeria ever since independence.

It is disheartening to observe that during electioneering campaigns, voting and collation of election results, thugs and hooligans were seen

${ }^{21}$ In this operation political thugs were employed to douse their opponents with petrol and set them alight.

${ }^{22}$ Philip Olusegun Ajimotokin, Thuggery in Politics: Slam on True Democracy (Lagos: New Bay Ventures, 2003), pp. 11-22.

${ }^{23}$ Ibid., p. 19.

${ }^{24}$ Ibid., p. 21. 
terrorizing the masses who wanted to enact their civic rights. It got to the extent that many candidates were assassinated before the election including Chief Bola Ige, Dr. Harry Marshall, Chief A.K. Dikibo, and others. The assassination of Dr. Ayodeji Daramola and Funsho Williams, both gubernatorial candidates of the ruling Peoples' Democratic Party (PDP) for Ekiti and Lagos States respectively, also speaks volumes about the dangerous political situation in the country. The situation was so bad that thugs and hooligans brandished their weapons openly at political gatherings in front of security operatives who watched on helplessly as though the acts of the thugs had been legalized were legal. The election period is seen as a busy period for thugs who become useful instruments in the hands of corrupt politicians who supply them with "Indian hemp, ogogoro, locally-made and pocketable fire arms and of course, good cash." 25 The big question then is should women be actively involved in such a political atmosphere which tends to confirm the alleged dirtiness of the game? Little wonder then that scholars of Islam vehemently reject women's participation in politics, while those who participate are seen as not being upright citizens.

\section{Midnight Meetings and Intermingling with Opposite Sex}

It is interesting to note that politicians are good at organizing meetings. Most of the meetings are held at night to strategize their action plans and other logistics for them to win elections. This implies that for a woman to be an active participant in politics, and for her to have a say in the decisions of her party, she has to be regular attendant at meetings wherever and whenever they are held. If she is married, her husband will have to excuse her almost every time she goes to meeting. If she is a mother, her children mayfeel the absence of their mother from home when she attends night meetings. For whatever reason, Islam does not support a woman to go out alone in the night without being accompanied by her husband. The excuse of going to a meeting may also be a license for her enter into immoral relationships outside the matrimonial home. Her husband may also become suspicious of his wife and this may generate lack of trust in the family.

As an addendum to the above, the involvement of a woman in active politics implies her intermingling of men and this can develop to immoral relationships among them. Islam wants decent relationships

${ }^{25}$ K. Esinulo, "Election Rigging as Big Business", The News, vol. 25, no. 12 (2005), p. 15. 
among the opposite sex, hence the cold attitude of traditional ulama to women's participation in politics.

\section{Problem of Godfatherism}

One of the commonest features of politics in Nigeria is the phenomenon of godfathersim. It is regarded as a crude and desperate struggle for state power by all means and at all costs using a superior patron for the purpose of advancing his political mercenary or partisan endeavours. Chukwuma and Otegwu define a godfather as, "a man of influence and affluence who supplies patronage access, protection or openings to a subordinate (godchild) who for his/her part pays back by supplying mercenary services in the form of economic, sexual, or psychological gratification. ${ }^{26}$ Some of the characteristic features of godfatherism as discussed by Chukwuma and Otegwu as manifested in the Nigerian political scene are very relevant to our discussion here. One of the characteristics is that the practice involves the bringing together of two unequal entities, the godfather and the godson with the former occupying a super-ordinate position and the latter subordinate. In this context, a female candidate becomes exclusively dependent on a godfather who imposes his lordship over the goddaughter. Further, the system involves a reciprocal relationship where both actors are involved in a sort of giveand-take relationship. It is observed that this reciprocal relationship does not in any way mean equality between the two parties involved, but that the godfather assumes a superior position and determines the fate the subordinate. This adds more to the fear of muslim scholars who feel that such a relationship could lead to committing adultery if the godfather should demand this from the goddaughter. What then happens when the goddaughter refuses to honour the initial agreement made with her godfather after being vested with the reins of power? In most cases, the state is made ungovernable for her through incessant tension and crises. She may either be abducted and sacked as happened in Anambra State between 1999 and 2007, or be impeached as in the case of the Oyo State governor in January 2006.

From all indications, the Islamic rule on khulwah could hardly be observed in a godfather-goddaughter relationship and this could generate wrong thoughts and sexual feelings which could lead to lack of trust in one or both of them. Such intimacy could hardly allow lowering of gazes

${ }^{26}$ O.A. Chukwuma and I. Otegwu, "Godfatherism and Political Crises in Nigeria 1999-2006", Mambayya House Journal of Democratic Studies, vol. 2 (2010), p. 80. 
on the part of the two as enjoined by the Quran (24: 30).

\section{Women and Islamic Injunction on Nakedness}

It needs to be mentioned that traditional ulama refer to the Quran (33: 59) as the justification for women to completely dressed in purdah. This may be difficult to accomplish in the present situation of politicking in the country. In Islam, the woman's whole body is considered awrah (naked) and must not be exposed. Even her voice is considered by some scholars as awrah, and so she must not be found talking in public. In that way, the assignment and work of women is strictly restricted to their home and under no circumstance should they go out canvassing for votes or declaring publicly their preference for a candidate. To these scholars, therefore, the singing and dancing of some women during political campaigns is grossly against the spirit of Islam. The point made by these ulama is that there is a hadith which prohibits women from going to mosques to pray, and if this is so, then, it therefore becomes forbidden for them to go out of their homes campaigning and dancing. The hadith reads:

Once the wife of Abu Hamis Sa'adi pleaded with the Prophet to be allowed to attend his mosque (the Prophet's mosque in Madina) as she was very fond of offering prayers behind him. He told her, "What you say is right, but it is better for you to offer prayer in a closed room than in a courtyard. Your prayer in a courtyard is better than on a veranda, and your offering prayer in the mosque of your own locality is better than coming to our mosque for it." ${ }^{27}$

The fact that women are not expected to go to mosque for worship is an indication that their sanctity is preserved even while performing their religious duty, not to talk of participating in party politics which allows them to freely mingle with men. However, such scholars do not consider some other hadith of the Prophet which permit women to attend mosques $^{28}$ and the modern development where women are now working in offices and factories.

${ }^{27}$ Doi, Islam in Nigeria, p. 29.

${ }^{28}$ For example, a hadith says: "Do not prevent the female servants of Allah from going to the mosque"; another hadith says: "When your womenfolk ask you for permission to attend the mosque, do not prevent them”. See Ibid., p. 28. 


\section{Islamic Etiquette and Political Practices}

In addition to the above, it is the belief of traditional ulama that women's participation in politics involves travelling out of their homes to attend political meetings and functions, and this could encourage corrupt people to prey on them. Their condemnation of this practice is premised under a hadith of the Prophet which says: "no woman who believes in Allah and the Last Day should travel a distance of three days journey or more, unless her father, son, husband, brother or other mabram ${ }^{29}$ is with her. ${ }^{30}$ Such scholars also look with contempt upon the social custom of men shaking hands with women who are not their mabram. The gravity of this simple act is buttressed with the saying of the Prophet that, "if one of you were to be stabbed in the head with an iron needle it would be better for him than touching a woman whom he is not permitted to touch." ${ }^{31}$ This experience in the political situation of the country makes it difficult for Muslim women to participate fully in it. Karwai therefore puts some challenges to muslim women who want to engagein politics in Nigeria. He writes:

Muslim women who are desirous of participating fully in the Nigeria Jaga-Jaga politics should get satisfactory answers to the following daunting questions: can they afford to attend nocturnal meetings which normally commence at 12:30am? Can they recruit first class assassins to eliminate a political opponent or his innocent wife? Can they stand the vagaries of hostage politics? Can they engage the services of political thugs/yan Daba, who will lift them up in political rallies and chant, say mai Kallabi? Do they have any exemplary female politician who is morally upright? Do any of them want their bosom mother to be like one of the popular female politicians in Nigeria? ? $^{32}$

\section{The Prophetic Saying on Women Leadership}

Most of the traditional ulama strongly depend on the content of a hadith to strongly oppose women participation in politics and their involvement in administration. The hadith reads inter alia, "when Allah's Apostle was informed that the Persians had crowned the daughter of

29 Mahram is relatives that forbidden to marry.

${ }^{30}$ Muhammad Salih Al-Munajjid, Muharramat: Forbidden Matters Some People Take Lightly (Riyadh: The Islamic Propagation, 2003), p. 73.

${ }^{31}$ Ibid., p. 69.

${ }^{32}$ Karwai Suleiman Abdullahi, "The Protection of the Rights of Women: An Islamic Perspective", The Journal of the Islamization of Knowledge and Contemporary Issues, vol. 6, no. 1 \& 2 (2006), p. 91. 
Khosran as their ruler, he said, such people, as ruled by a lady will never be successful." ${ }^{\prime 33}$ Although some scholars have faulted the authenticity of this hadith on the basis of the character of its narrator and for being narrated in Basra after the battle of Siffin where Aisha's forces were defeated by that of Ali's, the traditional ulama still uphold it. The argument that the Quranic Balqis, the Queen of Sheba negates the acclaimed Prophetic tradition on women's leadership seems untenable to the traditional ulama on the basis that she was not a muslim and she did not rule over a muslim state.

\section{Life-Styles of Women Politicians}

The life-styles of women who participate in politics after being elected into office are also of great concern for traditional ulama. As soon as they assume office, they move to the Government House or their official residence under tight security, leaving their husband's house. When their husband's goe with them, it becomes extremely difficult for members of the husband's family to have access to their relatives, as they become scared of the long protocol before they are being allowed in. Some see it as a wrong step for the husband to go to a building being secured at the instance of his wife. They believe that it is hard to find a woman like Khadijah, the Prophet's wife, in the contemporary period. Khadijah, though older and wealthier than her husband, surrendered herself and her property for her husband. In contemporary times, it is believed that women in politics are pompous and so cannot be obedient enough to their husbands, most especially in theera of women's liberation equality.

\section{E. A Case for the First Ladies}

From the above, one understands the fact that traditional ulama are not favourably disposed to women's participation in politics. However, it is our observation that whatever the case may be, it may be difficult for some women to exonerate themselves from participating in politics. Prominent in this case are the wives of political office-holders particularly those of the President and Governors. The creation of the Office of the First Lady at local, state and national levels has generated hot debate among scholars in Nigeria. To its opponents, the office does not receive any constitutional backing, and it is seen as a worthless venture that drains the nation's purse unnecessarily. Lack of continuity in the projects

${ }^{33}$ Al-Bukhāry, al-Jāmi al-Șaḥịh, vol. 8 (Beirut: Dār al-Fikr, 1981), p. 97. 
embarked upon by the occupants of the office soon after leaving it, also makes the office not worth its salt. ${ }^{34}$

An Office of the First Lady might not have been considered necessary in the early days of Islam. However, there is ample evidence that the wives of the Prophet were adequately recognised and honoured. The Quran expresses their elevated status by describing them umm al-mu'minin (Mothers of the Faithful) who should be addressed honourably and as well enjoy high respect from all muslims. Khadijah bin Khuwaylid, the first wife of the Prophet was said to have stood by her husband, giving him all the necessary support to ensure the success of his mission. Her love for him made her rush to Waraqah ibn Nawfal, her cousin, for advice and good counsel on the experience of her husband on his first contact with the Angel. She, therefore, encouraged him with predictions of success and declared her faith in his prophethood. ${ }^{35}$ Aisha, another prominent wife of the Prophet was also active in giving political support to her husband to the extent that she featured in the military campaigns made of the Prophet. ${ }^{36}$ It is also on record that the wives of such Abbasid caliphs as Mahdi (775-785CE), Ar-Rashid, (786-809CE), and Al-Ma'mun (813-833CE) went to war and commanded troopsin support of their husbands. ${ }^{37}$ The Office of the First Lady therefore,cannot be said to be totally against the spirit of Islam, as Islam seeks the support of wives for their husbands in all their endeavours, as long as the husbands have not derailed from the injunction of Allah.

\section{F. Concluding Remarks}

By nature of her biological make-up, no man can excel or even do better than a woman in the task of carrying pregnancy, delivering the baby, suckling him?, bringing him? up and caring for him. These are considered primary tasks for a woman which nobody can do for her. These tasks are enormous and time consuming such that facing these alone are enough

${ }^{34}$ Rashid Oladoja Lasisi, The Image of Africa: Rhetoric and Reality of Afro-European Relations (Nigeria: Library and Publications Committee, University of Ilorin, 2011), pp. 36-8.

${ }^{35}$ Mohammad Husein Haykal, The Life of Mubammad (London: Shorouk International, 1982), pp. 76-8.

${ }^{36}$ Ademola A. Popoola, "Models of Womanhood: The Case of Mothers of the Faithful", Religious Forum Academia (REFA) National Journal of Contemporary Issues in Religious, Arts and Social Studies, vol. 1, no. 1 (2010), pp. 49-50.

${ }^{37}$ Philip K. Hitti, History of the Arabs: From the Earliest Times to the Present (New York: Palgrave Macmillan, 2002), p. 333. 
for her. As a mother she is seen as entitled to three times the devotion given to the father from the children. In our view, it amounts to injustice that a woman should do all these tedious tasks and be saddled with other secondary responsibilities of providing sustenance for her family, which is the primary role for men. She, however, becomes selfish and an ingrate should she decide to leave her primary assignment of taking care of home for a task that is meant for the male. She is therefore seen leaving what she knows how to do best for what men can do better.

The failure of men in providing food, maintaining law and order in the community, waging war against enemies, and going on expeditions in search of new lands, adventure and treasure and even in their nonperformance in politics is due to the fact that the pillars (women) who are supposed to take care of home have left their primary duty undone and their endless requests from them. The society is therefore full of untrained children constituting obstacles to community development, making life uncomfortable. the resultant effect of this is that rather than focusing on developmental projects that would make life better, governments now earmark the highest percentage of their budgets on security, which could have been ensured at individual homes should those in charge (women) have not left their primary assignment for the secondary by competing with their male counterparts. The fact that women are now actively involved in politics in some countries and are now making progress by occupying highest political offices ${ }^{38}$ is not enough reason to generalise women's participation in politics. Even if such personalities have performed far better than their male counterparts, it should not be generalised, as there are few men who can also cook better than some women.

From all indications, it can be said that Islam does not go against women's participation in politics. However, the apprehension of traditional muslim scholars orients around the extent to which they could combine their traditional primary roles with politics, which is secondary, as well as how their involvement in politics would not jeopardise their religious tenets in view of the rough and insane nature of politics in the country. It is therefore the stand of these scholars that it is better for women to forgo their political participation as it prevents them from

${ }^{38}$ About nine women aspirants were able to make it to the last stage of the screening process in the election that produced Ahmed Nejard, a woman mayor equally emerged in Isfihan, while one of the twelve councils in Tehran was a woman. For more see: Opeloye, “The Muslim Women”, p. 11. 
performing their obligatory primary roles and affects the honour and dignity accorded to women in Islam.

For credible muslim women to be active in politics therefore, we suggest that special consideration should be given women in terms of night meetings, involvement in public campaigns, public singing and dancing, and indiscriminate intermingling with men who are not their husbands or relatives. For such women to be integrated into politics, their husbands too should be encouraged to participate fully in it to ensure mutual cooperation and harmonious family and society. Where a husband objects to his wife's participation in politics, such a woman should, as a matter of fact, oblige her husband's wish. Finally, there is serious need for muslim scholars to organise forums for muslim women in politics on the need to operate within the limits of Islam for them to win Allah's pleasure which is the ultimate goal for all. Muslim women cannot afford to maximise their achievements in this mundane world at the expense of the hereafter which is eternal. 
The Apprehensions of Traditional Ulama towards Women

\section{BIBLIOGRAPHY}

Abdullahi, Karwai Suleiman, "The Protection of the Rights of Women: An Islamic Perspective", The Journal of the Islamization of Knowledge and Contemporary Issues, vol. 6, no. 1 \& 2, 2006.

Abdullahi, Muhammad Sifawa, "Women Leadership: An Islamic Perspective", Al-Nabda: A Journal of Islamic Heritage, vol. 2, no. 1 \& 2, 1999, pp. 45-56.

Ajimotokin, Philip Olusegun, Thuggery in Politics: Slam on True Democracy, Lagos: New Bay Ventures, 2003.

Al-Bukhari, al-Jāmi` al-Șah̄ih, vol. 8, Beirut: Dār al-Fikr, 1981.

Chukwuma, O.A. and I. Otegwu, "Godfatherism and Political Crises in Nigeria 1999 - 2006", Mambayya House Journal of Democratic Studies, vol. 2, 2010.

Doi, A.R., Islam in Nigeria, Zaria: Gaskiya Corporation Limited, 1984.

Esinulo, K., "Election Rigging as Big Business", The News, vol. 25, no. 12, 2005.

Haykal, Mohammad Husein, The Life of Mubammad, London: Shorouk International, 1982.

Hitti, Philip K., History of the Arabs: From the Earliest Times to the Present, New York: Palgrave Macmillan, 2002.

Jamiu, S.M., "An Appraisal of Sex, Politics and Polity Among the Nigerian Muslim Women", in The Muslim Woman and the Challenges of the Contemporary Society, ed. by Yahya Oyewole Imam, Plateau State Nigeria: NATAIS [Nigeria Association of Teachers of Arabic and Islamic Studies], 2008.

Khan, Muqtedar, "Constructing Identity in 'Glocal' Politics", American Journal of Islamic Social Sciences, vol. 15, no. 3, 1998, pp. 81-106, http:/ / works.bepress.com $/$ cgi $/$ viewcontent.cgi?article $=1031 \&$ context $=\mathrm{m}$ uqtedar_khan, accessed 6 Jun 2014.

Lasisi, Rashid Oladoja, The Image of Africa: Rhetoric and Reality of AfroEuropean Relations, Nigeria: Library and Publications Committee University of Ilorin, 2011.

Al-Munajjid, Muhammad Salih, Muharramat: Forbidden Matters Some People Take Lightly, Riyadh: The Islamic Propagation, 2003.

Nasiru, Wahab O.A., “The Attitude of Traditional 'Ulama' to Muslim 
Adebayo Rafiu Ibrahim

Female Education in Nigeria", Muslim Education Quarterly, vol. 14, no. 2, 1997, pp. 69-79.

Opeloye, Muhib O., "The Muslim Women and the Challenges of the Contemporary Time", Journal of Nigerian Association of Teachers of Arabic and Islamic Studies, vol. 9, 2006, pp. 1-20.

Popoola, Ademola A., "Models of Womanhood: The Case of Mothers of the Faithful", Religious Forum Academia (REFA) National Journal of Contemporary Issues in Religious, Arts and Social Studies, vol. 1, no. 1, 2010.

Qutb, Muhammad, Islam: The Misunderstood Religion, Riyadh: International Islamic Federation of Student Organizations, 2006.

Rida, Muhammad Rashid, Huqūq al-Nisä’ fi al-Isläm: Nidà'’ al-Jins al-Latīf, Beirut: al-Maktab al-Islāmi, 1975.

Sulaiman, I.K.R., "The Shari'ah and the 1979 Constitution”, in Islamic Law in Nigeria: Application and Teaching, ed. by S.K. Rashid, Lagos: Islamic Publication Bureau, 1986.

Uthman, Abd Al-Karim, "The Socio-Economic Status of Women in Northern Nigeria: An Analysis of The 1804 Jihad Movement", AlIjtibad: Journal for the Islamization of Knowledge and Contemporary Issues, vol. 8, no. 1, 2010. 